Available Online at https://journal.unismuh.ac.id/index.php/otoritas

Otoritas : Jurnal Ilmu Pemerintahan, 11 (1), April 2021, 19-32

\title{
Resistance Against Corporation by the Religion-Based Environmental Movement in Water Resources Conflict in Pandeglang, Indonesia
}

\author{
M Dian Hikmawan'*), Ika Arinia Indriyany1, Abdul Hamid1 \\ ${ }^{1}$ Department of Government Studies, Faculty of Social and Political Sciences, Universitas Sultan \\ Ageng Tirtayasa, Serang, 42124, Indonesia
}

Received: 31 March 2020; Revised: 1 March 2021; Accepted: 27 April 2021

\begin{abstract}
Natural resource conflicts between corporations and local communities were quite common in Indonesia. In an area in Pandeglang-Banten, a giant corporation tried to control the natural resources, especially in this case is water resource, and the local religious based community fought against the corporation's agenda. This paper describes the formation of a religious-based community doing social movement against a big corporation in Pandeglang, Banten Indonesia. The research method uses qualitative with case study strategy. The research location was in Cadasari District, Pandeglang Regent, Banten Province, Indonesia. This paper shows that the social movement succeeded to defend their accesses to water resources through religious doctrine easily understood by local people under the leadership by the local religious leaders (Kyai) from local Islamic schools (Pesantren). They share collective identity, as victims of the company project and also a moslem. The collective identity as victims as well as moslems, linked by dense religious informal networks and corporation and local government as clear enemy made their movement successfully terminated the company project. As a main actor, Kyai played significant roles to mobilize people in this social movement. Using her charismatic character, Kyai was able to defeat legal-rational leadership such as local government and security forces.
\end{abstract}

Keywords: Corporation; Kyai; Pesantren; Social Movement; Water Resources Conflict

How to Cite: Hikmawan, M. D., \& Indriyany, I. A. (2021). Resistance Against Corporation by the Religion-Based Environmental Movement in Water Resources Conflict in Pandeglang, Indonesia. Otoritas : Jurnal Ilmu Pemerintahan, 11(1), 19-32.

Permalink/DOI: https://doi.org/10.26618/ojip.v11i1.3305

${ }^{*}$ Corresponding Author.

E-Mail : dian.hikmawan@untirta.ac.id

Copyright (C) 2021, Otoritas : Jurnal Ilmu Pemerintahan, ISSN: 2088-3706 (Print), ISSN: 2502-9320 (Online) 


\section{INTRODUCTION}

Natural resource conflicts were rather prevalent in Indonesia. According to data collected by the Indonesian Huma Association, as of December 2018, there were 326 natural resource (SDA) and agrarian conflicts in Indonesia. The conflict took place in 158 districts and cities in 32 provinces with an area of $2,101,858,221$ hectares and involved 286,631 lives, consisting of 176,337 indigenous peoples and 110,294 local people (Huma, 2019).

Conflicts involve the government, the community and also the private sector. Often, the trigger for conflict is Indonesia's natural wealth which is exploited by large companies. As the consequences, natural environment such as sea, river or soil suffered damage. Conflicts because of over-exploitation in recent years occurred in various areas in Indonesia.

This exploitation often harms the community and creates resistance in the form of social movements. However, this conflict often runs unbalanced because the state is usually on the side of the company's interests. Focus on environtment demaged, this research tries to elaborate how the awaking of citizens to fight the explotation in resources. The interestings is how the rise of movement is arised by religouse symbol and agent. That's become the interestings phenomenon in this research. Discussion about environmental movement in Indonesia, we can learn from several phenomenon which give us reference to explore about environmental cases in Indonesia.

In the case of reclamation issues also there is depolitisation in process of environmental governance as a public issues (Hikmawan \& Hidayat, 2016). In this research describe how the depolitisation in reclamation policy of Beno bay in Bali. The community in Bali devided in two community who against and support on facing this reclamation issues. The com- munity who against the reclamation issue build the community and it's called ForBALI (Forum Rakyat Bali Tolak Reklamasi/Bali's Society Forum Againts Reclamation). ForBali try to against the reclamatiion in Benoa bay through enggagement community and involve the peaople in Indonesia even international community who care about environmental issues in Bali.

In the case of the Lapindo mudflow in Sidoarjo which is detrimental to the wider community, the Police issued a warrant for terminating the case investigation which made the investigation of the Lapindo Mud case unable to be processed further in court.

Another example is the case of the expansion of PT Semen Gresik (SG) into the North Kendeng Mountains in Pati Regency, Central Java (Central Java), where the Pati District Spatial Plan of Pati Regency was tried to be adjusted to the interests of PT SG's expansion. The the North Kendeng Mountains area in the 1993-2012 the Pati District Spatial Pati Regency, included in the agricultural and tourism area, was intended to be converted into an industrial and mining area in the Central Java Province the Pati District Spatial 2009-2029. Here we see that the the Pati District Spatial document actually wants to be 'adjusted' for the interests of PT SG's expansion into the North Kendeng Mountains in Pati Regency. The third example is the corporate victory in the Lapindo Mud case trial and Sorikmas Mining in the Supreme Court (Batubara, 2013).

In current Banten, the issues of corporate controlling the natural resources became contentious. The purpose in this paper is to explain the case of the resistance of community against corporation in Banten. The community in Cadasari, Pandeglang-Banten, expressed the resistance toward a bottled-water factory trying to exploit the water resources. The locals were against drinking water plant owned by PT. Tirta Fresindo Jaya. Hence, 
the resistance emerged the form of a religious-based social movement.

Social movements as political resistance that occurs when ordinary people join community groups that more influential in mobilize to fight the power elite, authorities and other opponent parties (Tilly \& Tarrow, 2007). Social movements can be defined also as a continuing gradually action by making collective demands of the other party (Tilly \& Tarrow, 2007).

Sztompka imposes limits the definition of a social movement (Martono, 2011). According to him, social movements must have four criteria, namely: first, the collectivity; second, have the shared goal, which is to realize certain changes in their society participation defined in the same way; Third, the collectivity relatively scattered but lesser than the formal organization. Fourth, its actions have a high degree of spontaneity but are not institutionalized and unconventional shape.

The collective action is an element that is quite important for the formation of a social movement. Because collective action will be formed when the individuals with full consciousness and rationality want to get involved to act on behalf of collective goods. Thus, the beginning of

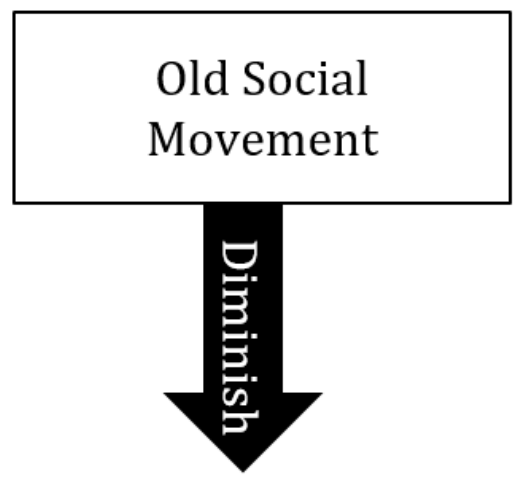

Materials/Money the formation of social movements will be dominated by community awareness who have organized and autonomous individuals unite into movement.

The environmental movement itself is within the category of new social movements. New social movements see other logic underlying someone act collectively. The old social movement assumes that people want to do collective action based on economic factors. New social movement see that people are willing to act may be not due to economic factors but could be the basis of ideological, political, cultural or other identity sources that are used as roots movement. On the basis of this ideology the neighborhood-based social movements can be included as a new social movement (Laclau \& Mouffe, 2001).

Social movements are a distinct social process, consisting of the mechanisms through which actors engaged in collective action: (1) are involved in conflictual relations with clearly identified opponents; (2) are linked by dense informal networks; (3) share a distinct collective identity (Porta \& Diani, 2006).

In the environmental issue, the actor of social movement -local people or environmental organization engage with government or corporation in conflict relationship. It means opposition relationship

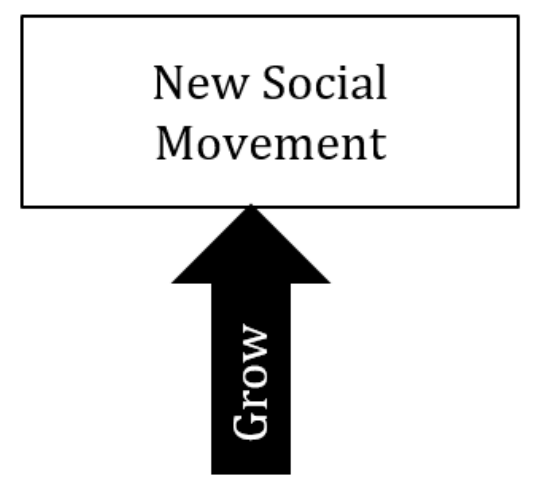

Relationship, Commitment Community

Figure 1. Old Social Movement and New Social Movement Source: Laclau \& Mouffe, (2001) 
between actors who seek control over the same interests, be it political, economic, or cultural forces that make negative claims and demands of each other which if realized will damage the interests of other actors (Porta \& Diani, 2006).

Dense informal networks differentiate the process of social movements from other forms of collective action. In social movements, both individuals and organizations are in a position to maintain their autonomy and independence, exchanging sustainable resources to achieve common goals. In the process, coordination occurs continuously in the form of permanent negotiations between the individuals and organizations involved. That is why there is no single coordinator who can represent a social movement as a whole. The opportunity to appear depends on the commitment and skills of individuals involved in the political process in social movements.

Social movements only occur when collective identity develops and goes beyond certain events and initiatives. Collective identity is closely related to the recognition and creation of connectedness that brings with it shared goals and commitments that allow an individual and organization to feel intimately connected with other factors that do not have to be identical but are definitely compatible, in broader collective mobilization (Porta \& Diani, 2006).

In social movements, membership criteria are very unstable and ultimately depend on mutual recognition between actors to define who is part and not part of the network. Building collective identity also involves actors who build relationships between different events, personal and public, which are located at different points of time and space, which are relevant to their experiences.

As a result, organizational actors and individuals involved in collective action no longer only pursue certain goals, but then consider themselves to be ele- ments of a much larger process of change and encourage - or resistance to change (Porta \& Diani, 2006).

The development of the environmental movement into three categories: First, a group concerned with the preservation of the countryside as a wonderful place to escape from all the fatigue for the people living in the urban-industrial areas. Second, a group that cares for nature conservation with scientific reasons. Third, the groups are specifically interested in efforts to protect certain animals (Suharko, 1998).

The green movement (environment) expanded rapidly in the 1950s were marked by a number of members grew, and the widespread public concern. There are two main characteristics: appears in the form of mass movement and highlighting the interdependence between environmental problems than the single issue of air-movement.

This movement corresponds to the increasingly acute environmental crisis. There are two phases in the environmental crisis. The first is the first crisis, which triggered by the book Rachel Carson: Silent Spring, in the form of a critique of the impact of pesticide use, and large-scale production. Its main focus is the partial environmental degradation such as pollution of river water, or impact on health.

The second phase, the environmental crisis that neither root nor cause a phenomenon of global scale. According to Homer and Dixon (Suharko, 1998), there are six sources of causes of the global environmental crisis: climate change caused by the greenhouse effect, ozone layer depletion, degradation and loss of fertile agricultural land, degradation and deforestation, reduction and supkai water and the depletion of fishing grounds. Sixth sources such environmental changes, coupled with population growth and uneven distribution of resources, has led to what is known as environmental scarcity.

Actor or agent of the green move- 
ment according to Parkin (Suharko, 1998), can be divided into four categories: (1) Those who give practical examples of how to implement a lifestyle "green", which includes the organic farmers, who developed the technology alternative, and others. (2) single-issue pressure groups (3) those who work with the example and propaganda in the existing establishment, such as political parties, churches, universities, and others. (4) are distinctive: a green political party (green party).

Model environmental movement are in a continuum between the model reformer (shallow ecology-oriented viewanthropocentrism) and radical models (oriented view of ecology in ecocentrism). Environmental movement split into three models: (1) instrumental movement close to the reformist movement models, (2) a counter-cultural movement that is close to the model of the radical movement, and in the center of it there is a sub-cultural movement (Heijden, 1999).

Instrumental movement is divided into three social movements: (1) Conservationists, a movement that has a major concern in the protection of nature or a specific natural area. (2) The policy campaigners, a movement that tried to influence environmental policy makers. (3) The mobilizers, a movement whose main activity drive the public in an environmental action either to the authorities or businesses that decision or behavior is harmful to the environment.

Environmental activists tend to come from the lower classes, especially from the poor, women and national minorities (Haynes, 1999). Environmental campaigns may only succeed under certain conditions. First, there is a democratic and legal space to encourage environmental issues. Second, the importance of building a group of organizations and organizations that are relatively broad, quite large and quite representative of the state and its allies, such as large landown- ers, senior military figures or important business interests. Third, such a struggle may only succeed in a democratic environment where strong civil society has an influence on the state.

Nevertheless, there are different views about the issues that led to the birth of environmental social movements. If in Korea, Taiwan and Hong Kong are similar to Western environmental discourses, which focus on negative impacts on human health, recreation and natural habitats, environmental discourse in developing countries such as the Philippines and Thailand is mainly driven by conflicts over livelihoods. The main vital problem is the survival of the poor.

If quality of life problems become a driving factor for the emergence of collective environmental actions in East Asia and in the West, environmental conflict in Southeast Asia is a form of economic battle over livelihood problems and survival (So et al., 1999).

For example, conflict on groundwater resources in the Netherland. Such conflict happened in The Mander nature area, The province of Overijssel between the regional public company Vitens, coowned by the Provincial Council of Overijssel (PCO) and NGO Landscape Overijssel who manage the conservation of natural habitats, fauna and flora in that area (Dinica, 2015).

In developing countries like Indonesia when in decentralization era, the local governments have right to issued license to corporation to exploit natural resource. On the other side local communities whose lives depend on natural resources feel disturbed and try to fight back. Because this happens in the era of democracy, this kind of resistance is possible.

For example, the conflicts between local communities and corporations in the North Kendeng Mountains, Central JavaIndonesia depart from a different perspective on the resources of the limestone mountains in the area. The two main par- 
ties have different goals. From the aspect of the issue, this conflict is based on values and interests. From the value dimension, indigenous people believe that limestone and the surrounding ecosystem must be preserved; while for corporations, limestone is a natural resource that can be used to improve people's welfare. Viewed from the dimension of interests, for indigenous peoples, the sustainability of the North Kendeng mountain ecosystem will provide water resources to guarantee their agricultural life patterns; while for corporations, the use of natural resources in these mountainous regions will increase business profits and at the same time have implications for regional and national economic revenues (Suharko, 2016).

Social movements are largely driven by basic principles that are believed by actors. Values will influence how actors define certain goals and identify efficient strategies that are morally acceptable. In addition, values will provide the motivation needed to sustain the costs of action. The more intense one's socialization to a particular world vision, the stronger the drive to act. The characteristics of a given value system will form the action component (Porta \& Diani, 2006).

\section{RESEARCH METHODS}

This study is a qualitative case study type. For qualitative research, this study sought to explore and understand the meaning by individuals or group of people ascribed social or humanitarian issues. The research strategy or the type of research is a case study. Qualitative research is a case study research strategy where researchers investigate carefully a program, event, activity, process, or group of individuals. The cases are limited by time and activity, and researchers collected detailed information using a variety of data collection procedures based on a predetermined time (Creswell \& Creswell, 2018).
In gathering the data, Researchers use to study documents and interviews. Documents collected are a note describing various community resistance to corporate events, both formal documents, informal, and the news media. Studies carried out to establish the construction documents and be a material event for the second method, namely the interview. Indepth interviews will be carried out against those involved in the incidents were investigated. Selection of informants is purposive and snowball, especially to: religious leaders, community leaders, corporate parties, people involved in the action, government officials and security forces.

\section{RESULTS AND DISCUSSION}

\section{Social Setting}

Banten is a western area of Java Island. In general, the region is a former Banten sultanate known as the religious community. More specifically, Pandeglang district which is located on the western tip of Java island is known as the City of Santri (Pesantren Students). As a city of Santri, in Pandeglang there are many Pesantren (Islamic boarding schools) that form the patterned shades of Islamic culture and steeped in religious values with the majority religion of Islam.

As with other regions in Banten, in Pandeglang, Islamic scholars or Kiai has a position as a charismatic leader. Kiai's position as the elite can be explained by the concept of charismatic authority of Max Weber. Charismatic authority is authorized by the trust of community members to the magic and the mystical or religious leader (Budiarjo, 2008). It could be said that Kiai is the person who acquire religious legitimacy through the expertise and knowledge of its religion.

In the context of Banten this is reflected in the history of Banten sultanate government that is led by the sultans were also Kiai. Syarif Hidayatullah (Sunan 
Gunung Jati) which established the Sultanate of Banten was known as a teacher of Islam, a major pillar of the spread of Islam in Banten. He and his son, Maulana Hasanuddin were religious scholars actively spread Islam. After the Banten Sultanate was abolished in Daendels period, the state became chaotic and the entire social order almost collapsed. In this situation, the leaders emerged from among kiai and other rural elite (Kartodirjo, 1984).

In connection with kiai role in political and social life, there are at least three expert opinion. First, the results Geertz research in Java, which concluded that the kiai has a role as a cultural broker (broker culture). In the period after independence, there has been a change in the role of kiai, of a communicator which connects the Islamic world based in Mecca with farmers in rural Java, changed the role of a politician who is an agent of the central government in the village. The Kiai, because of his position, plays a brokerage role for muslims to give them an understanding of what is going on at the national level (Turmudi, 2003).

Second, Horikoshi's research in Garut, West Java see that kiai not only did his role as a broker, but Kiai also had the role of social change with its creativity. Kiai was not only drown as a result of social changes, but pioneered social change itself. He did not only filter information, but rather to offer an agenda that considers changes in accordance with the needs of society he leads (Horikosi, 1987).

This is a refutation of Geertz opinion that as a Cultural Broker Kiai only serves as a link between the modern state with a traditional society where the broker selection where only culture that can be accepted and which should be rejected, as if to imply that the cultural broker does not have views and original approaches (Burhanuddin, 2000).

Following the political changes in contemporary post-reform. There is argu- ment that argued the Kiai was in a position as a political broker (Kuntowijoyo, 2001). Although not based on in-depth research as Geertz and Horikoshi, but Kuntowijoyo opinion was based on the role of scholars who conduct political activities by making authority in the field of religion and its followers as a political commodity in the era of liberal politics.

One of the most prominent Kiai in Banten was Abuya Dimyati (1930-2003). In his lifetime, he did not only teach the Santri (Pesantren`s pupils), but also provided a weekly teaching for religious leaders of pesantren kiai entire Banten. The books he teached is difficult and hard enough to be understood as Ihya Ulumuddin and Al-Mustasyfa are both written by Al Ghazali. Abuya Dimyati is also Mursyid tarikat Syadziliyyah in Indonesia. He was trusted by the students and the community have wisdom and superiority.

In the New Order era, Abuya Dimyati was arrested and imprisoned during the general elections of 1977, because of his statements, that considered attacking the government and Ruling Party - Golkar. On Friday, March 11th, 1977, before Friday prayer Abuya Dimyati said to local village head, so that people should not be frightened and intimidated by the interests of one of the contestants election, with a variety of threats, one of them with the statement that "Golkar is Government". Abuya Dimyati revealed that "the Government is Republic of Indonesia and not Golkar" (Dimyati, 2008).

One of the sons of Abuya Dimyati who continue charismatic leadership was Abuya Muhtadi Dimyati. In the present time, Abuya Muhtadi Dimyati lead pesantren Cidahu and inherited the mportant position not only in religious studies, but also in socio-political dynamics in Banten. Pesantren Cidahu located in District Cadasari which has environmental problems due to the influx of investment from PT Tirta Fresindo Jaya who want to make a bottled water plant which 
is of course potentially dominate and damage the springs in the area. Around Cidahu there are dozens of other pesantrens where pupils (santri) studying islam religion.

\section{Project and Resistance}

PT Tirta Fresindo Jaya is one of the subsidiaries of PT Mayora that imparts water business investments in Pandeglang - Banten. PT Mayora itself began doing business in Indonesia since 1977, through Coconut Confectionery products Rome. Not only biscuits, developing Mayora Business expansion into confectionery Kopiko, Wafer Beng - Beng, Chocolate Choki - Choki, Coffee Sachet Torabika, Mi Glass, Cereal Energen, Kopiko 78, Tea Shoots Harum, Le Minerale, etc. The amount of PT Mayora reflected in the company's assets reached Rp 12,922 billion as of December 31, 2016.

Expansion PT Mayora to the field of beverage began in 2011, with bottled water marketed Le Minerale through PT Tirta Fresindo Jaya. PT Tirta Fresindo Jaya is a subsidiary of PT Mayora which is focused on business lines Le Minerale water. Bottled water factory is spread from Cianjur, Palembang, Ciawi, Sukabumi,
Pasuruan, Medan and Makassar. In 2014, PT Tirta Fresindo Jaya planned to invest in the water business Pandeglang - Banten, Indonesia. In this year was the cause of conflict began to appear. Causes of conflict began to emerge when the Local Government (LG) Pandeglang permit the location and ground water exploitation permit to PT. Fresindo Tirta Jaya to establish a drinking water factory Le-Minerale (Kresna, 2017a).

Although permission was granted by the Local Government (LG) Pandeglang, the source of water at the site of PT. Fresindo Jaya included as part of the administrative district of Serang. Region that are at least 8 springs for the District Baros (Serang Regency) there are four water named Cilarangan, Cilisungbunian, Cikondang, and Cikopo, and in the District Cadasari (Pandeglang), there are four other springs named Cinangka, Ciwarasta, Kedu Bedul, and Kadu Bu'ut.

Then four springs in Cadasari was backfilled by gradually dredge agricultural land and settlements that have been purchased by PT. Fresindo Jaya. The land purchase was done through the village. Residents initially did not know the plan to build a drinking factory within its own

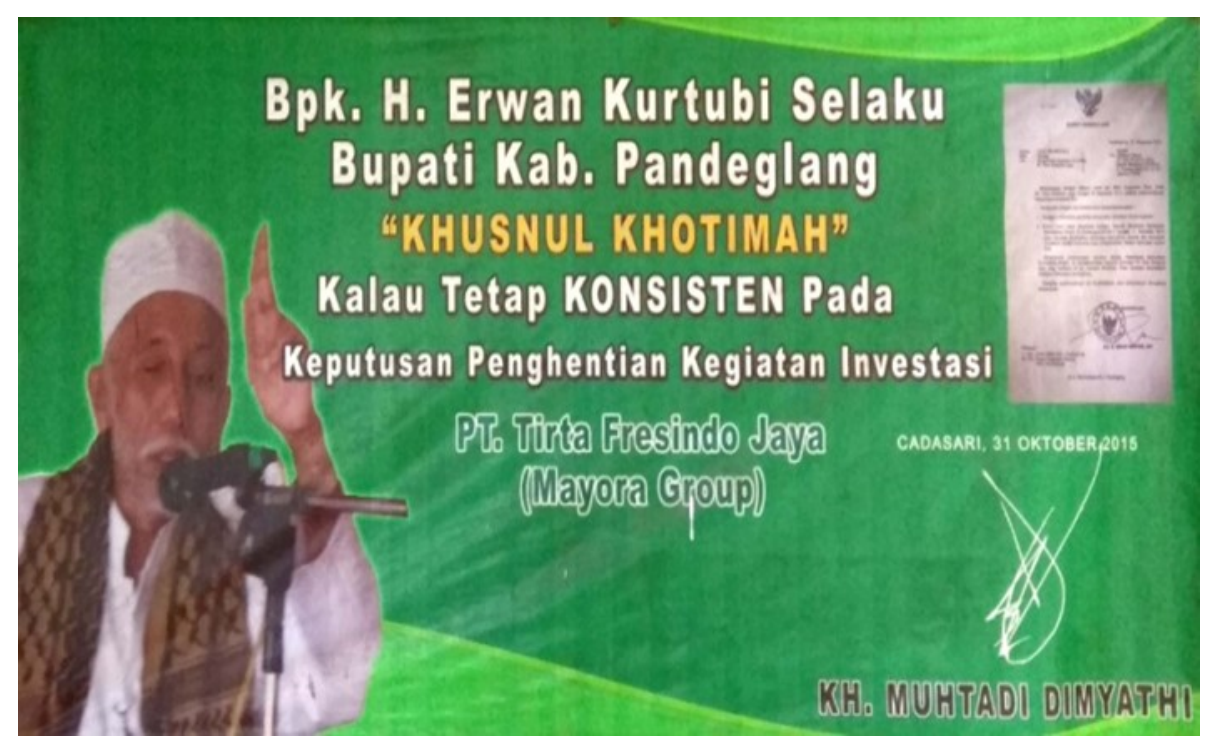

Figure 2. Project Rejection by Kyai (Islamic scholars)

Source: Poros.id (2018) 
territory. When the land acquisition happened at the end of 2013 villagers were told that the land used for housing (Kresna, 2017b). When stockpiling in late 2013 and especially when ground water extraction trials in early 2016, residents water reservoirs began shrinking and irrigation of farmland affected.

According to the Regional Regulation (Perda) 3/2011 About Spatial Plan (RTRW) 2011-2031 Pandeglang district, sub-district where the location Cadasari PT. Fresindo Jaya was designated as a protected geological area. In addition, because of the high productivity, the area was designated as an area of agricultural land springs of water and sustainable food. Because contains many water springs, the Cadasari area was included in thegreen zones in the map of potential water resources (Pandeglang Regency, 2011).

PT. Tirta Fresindo Jaya had asked permission since August 2013 and then in December the company received an approval letter from the government to build a (site plan) factory. Then at the same time, the activity of dredging settlement lands and paddy former residents who have been bought by the PT. Tirta Fresindo Jaya also started. On March 5th, 2014, the Pandeglang Regent H. Erwan Kurtubi gave permission to one Director of the Company Mayora Group to build the bottled water industry (Le-Minerale).

Then on May 22, 2014 the company has a permit exploitation of ground water in Jalan Raya Serang, Pandeglang Km 5, Kampung Keramat Gayam Musola Cadasari, Pandeglang - Banten with area reached 12 hectares. The building area is an area of 4.6 ha and the investment value of Rp. 250 billion.

There are two water well drilling facilities. The first well has a maximum capacity of 100 cubic meters per day, and a second well a maximum capacity of 75 cubic meters per day. The depth of these two wells reached 175 meters to drill wa- ter. This threatens water availability in eight springs that became the critical of daily life of citizens (Forum Anggota Dewan Sumber Daya Air Nasional, 2016).

The information that the company that will operate the water utility company was hidden by using the village apparatus as a land broker by saying to the people that purchase of land earmarked for housing.

The presence of PT. Tirta Fresindo Jaya alleged to have violated the rules of the Regulation (Regulation) 3/2011 About Spatial Plan (RTRW) Pandeglang Year 2011-2031. In the same regulation stated that the sub-district where the factory site cadasari including the water catchment areas (Article 31, paragraphs 1 and 2) geological protected areas (article 35 paragraph 4) and regional sustainable food agricultural land (Article 39, paragraph 6) (Pandeglang Regency, 2011).

Yet further, the presence of companies that control water resources, ignoring the aspect of local wisdom. In the completion of the project suggestions PT. Fresindo Tirta Jaya in Serang and Pandeglang district, Forum Board Member of the National Water Resources, NonGovernment Element stated that the first point of the negative impact of the presence of the PT project. PT. Fresindo Tirta Jaya is resulting in loss of 7 springs, sacred tombs and historical sites. The other two were: lack of water sources for public consumption, as well as 100 hectares of drought and water shortages to Tangerang (Forum Anggota Dewan Sumber Daya Air Nasional, 2016).

The religious-based community created the social movements against PT. Tirta Fresindo Jaya. This was not surprising because in some locations there were 42 traditional pesantren (salafi). In addition, the position of the project was in the Kramat Musola (Kaduawi) village, Cadasari district, Pandeglang (Ahmad, 2016).

In 2014 the movement began and 
organized by some Kyais as the pioneers. The Momentum was when on June 12, 2014 the Cadasri citizens held istighosah (praying together) at Honje Restaurant and agree to reject the project of PT Tirta Fresindo Jaya. Furthermore, throughout the month of June to August, the community is led by some Kyais such as $\mathrm{KH}$. Ubing Surohman, KH Muslim, KH. Nahrowi, KH Bai Didi, KH Ahmad Khusaeri, KH. Izzudin, KH Sonhaji. Along with local figures and Santris, they held various meetings with local government officials, the polices and the other various parties to express rejection of the project by PT Tirta Fresindo Jaya. Even at 17 September 2014 they held a peaceful protest at the Pandeglang Regency Office with thousands mass.

Recognizing the high intensity of the rejection of people around the project location, Pandeglang Regent H. Erwan Kurtubi finally issued the Notice letter in 21 November 2014 to the president director of PT. Fresindo Jaya: "Activities Termination of PT Tirta Fresindo Jaya". Before the letter was issued, there was a meeting between some Kyais, community leaders, and high rank local government official in Pesantren Kadu Kaweng.

However, in 2015, the project kept continue. Representative of PT. Tirta Fresindo Jaya through the village government aparatus trying to approach the Kyai. They came to Abuya Muhtadi and said that the project will be continued. Furthermore, they also held various meetings to socialize the plan to the citizens, facilitated by the village government.

Once again, people are getting restless. In a meeting attended by 118 Kyai, community leaders, military and police officers at boarding Riyadul Wildan Cadasari in Kampung Curug, they still expressed opposition to the project. They then declare the denial letter signed by KH. Husaeri Ahmad, chairman of Majelis Ulama Indonesia (Islamic Scholars Association) Cadasari and Abuya Muhtadi as
Banten Ulama leaders and submitted to the Regent Pandeglang. In addition to MUI, Jam iyatul Muslims Organization also submitted a complaint against the project PT. Tirta Fresindo Jaya, addressed to the Banten Police. Then, they organized a peace rally attented by thousands of people and made audience with the Banten Province local parliament on 11 November 2015. The local parliament agree to stop the project of PT. Tirta Fresindo Jaya (Ahmad, 2016).

However, the turmoil intensified until 2016 when PT. Tirta Fresindo Jaya continue to start the project works, that was considered to provoke the public. Refer to a letter from Ombudsman, PT. Tirta Fresindo Jaya even involve military officer from Special Forces Command Group 1 Serang to intimidate people and prevent rejection (Ombudsman Republic of Indonesia, 2016).

Even though repeated clashes can be prevented, finally it was happened. On January 13, 2016 in the location of fencing project, pof the company, angry people gathered at the site to prevent fencing, resulting in the collapse of the fence project PT. Tirta Fresindo Jaya along 50 meters.

After the incident, the police move quickly and asked official of PT. Tirta Fresindo Jaya to make report to the police. This attitude would increase anger and consolidation in the society. On January 28, 2016, the muslim community made big meeting, praying together in Mosque of Kyai Cangkudu initiated by $\mathrm{KH}$ Nahrowi, head of Pondok Pesantren Riyadul Awamil. The next day, residents gathered in the village of Kadu Awi, and in every village also implemented Istighosah. Citizens fear then proved when 10 residents consisting of Kyai, community leaders and youth, including $\mathrm{KH}$ Nahrowi then summoned by the Banten Police for questioning on February 5, 2016 (Ahmad, 2016).

But the turmoil resumed again in 
early 2017. On February 6, 2017 hundreds of people came to the Pandeglang regent's office stated their refusal to PT. Tirta Fresindo Jaya. Disappointed that they cannot met The Regent, the people then move to the location of the project. At the site, riots happen. Residents broke down the door of PT. Fresindo Jaya while throwing stones / bottle and Molotov into the company so that the combustion of heavy equipment and damaged buildings in the project (Arbi, 2017). A day later, three residents were arrested. Impact of the amok, finally the Acting Governor of Banten Nata Irawan through Banten Governor Decree No. 050/700-BAPP/2017 states that the business permit of PT. Tirta Fresindo Jaya was expired (Putra, 2017).

Religious-Environmental Movement in the Unfreeze Stage

This study proves that the environmental conflict in Pandeglang arose because of the efforts of the local lower class to maintain their survival (So et al., 1999). This is different from in East and West Asian countries where environmental discourse is a negative impact on human health, recreation and destruction of natural habitats. The growing discourse on environment and triggering environmental social movements in this study is the threat of the severance of community access to water resources. This threatens the lives of the majority of farmers.

This environmental discourse meets with the fact that corporate action does not only threaten people's livelihoods. The area of corporate operations includes dozens of pesantren which are highly dependent on water for daily life and also ritual worship. As a result, environmental issues are mixed with religious issues. So, the social movement clearly can be seen as the Religious -Environmental Social Movement. As important value in society, religion have influence for social movement, especially in religious community.
The role of religion is a significant element in determining a society's view of nature and the environment. The christianity in the west countries, hinduism in India, catholic in The Philippines and Budhism in Srilanka gave a view how people living harmoniously with the environment and building movement without violence (Doyle \& Dough, 2008).

In Indonesia, based on his research in conflicts between local communities and mining companies in Manggarai, sometimes Church played a major role in building social movements (Regus, 2017). Church promoting several key principles such as 'pro-life' development, ecological sustainability, continuity of local culture, economic prosperity and social justice. The church is effective in building and guaranteeing resistance without using violence. The Church also uses its own national and international networks to voice concerns about the effects of mining, and raise issues that affect the natural, social and cultural landscape of the area.

Pesantren become the basis of resistance, religious values become the main spirit of social movements, and local religious leaders (Kyai) become respected leaders. In the context of the religious Pandeglang society, Kyai as a charismatic leader plays an important role and authority that cannot be denied. Fighting against corporations has a rewarding worship value. Kyai leadership able to mobilize citizens not only faced with the corporation, but also local governments, even the security apparatus.

This is interesting because in some studies about the social and political role of Kyai, there are several studies that positioned Kyai as political brokers, especially in the event of some sort of electoral politics (Hamid, 2010); (Turmudi, 2003). Leadership of Kyai to organize social movements against control of water resources by the corporation showed that Kyai in the community still has an im- 
portant role as actors of social change. they did change by their social creativity.

In this case, Kyai not only dampen a result of social change, but pioneered and led social change itself. They not only as source of information, but rather to offer an agenda that considers changes in accordance with the needs of society they lead. Social movements in Cadasari can be explained as collective action based on three process (Porta \& Diani, 2006). The first, are the actors involved in conflictual relations with clearly identified opponents. The community had clearly enemies: the company that stolen their water and government that support them.

Second, they are linked by dense informal networks. The informal organization was more powerfull than formal organization. For example, the community made some informal group and forum, led by local religious leader to organize a movement. It more trustworthy and effective than formal religious organization such as Majelis Ulama Indonesia who tend to cooperated with government.

Third, the actors share a distinct collective identity. The actors in not only the victims of the project, but also have the same identity: moslem community. Key figures in the resistance movement are the Kyai, both as a symbol like Abuya $\mathrm{Mu}-$ htadi, as well some Kyais who directly organizing in the field. Various consolidation meeting also largely conducted at the Pesantren. The method implemented, in addition to common methods such as demonstrations or hearings also praying together (istighosah). Religion gives energy and legitimacy to the resistance of citizens to PT. Tirta Fresindo Jaya. As Social movements is largely driven by basic principles that are believed by actors. Values will influence how actors define certain goals and identify efficient strategies that are morally acceptable. In addition, values will provide the motivation needed to sustain the costs of action (Porta \& Diani, 2006).

\section{CONCLUSION}

In this case, social movements built as a collective action against businesses that tried to control natural resources, in this case the water source. The source of water is the basic needs of society and the corporate domination would eliminate public access to the water source and the source of their life as a farmer. Agricultural environment that rely on water sources endangered. Resistance was also submitted to the government as a regulator that gives permission for the corporate business activities.

Kyai become a main actor in mobilizing people as well as Religion became important value as main spirit of the social movement. Pesantren is not only a place studied religion but became a consolidated basis to take the fight with the various actions that has religious nuance. Kyai as charismatic leadership was able to defeat a legal- rational leadership such as local government and security forces. Both of them were considered to facilitate business actions detrimental to society.

In this case Kyai role as actors of social change, which not only offers an agen$\mathrm{da}$, but to lead the change agenda. Mobilizer social movements is at least capable of fighting and stopping business activity considered damaging to the environment and harmful to society.

In the community, they share collective identity, as victims of the company project and also a moslem. The collective identity, linked by dense informal networks and clear enemy made their movement successfully terminated the company project.

\section{ACKNOWLEDGEMENT}

This work was supported by Department of Government Studies, Faculty of Social and Political Science, Sultan Ageng Tirtayasa University, under Grant 2018. 
Available Online at https://journal.unismuh.ac.id/index.php/otoritas

Otoritas : Jurnal Ilmu Pemerintahan, 11 (1), April 2021, 31

\section{REFERENCES}

Ahmad, I. (2016). Perlawanan Kyai di Banten, Epik Modern Pesantren Salafiyah. Banten: Pustaka Empat Lima.

Arbi, A. (2017). Warga Amuk PT. Mayora, Satu Alat berat Dibakar. Radar Banten. https://www.radarbanten.co.id/ warga-amuk-pt-mayora-satu-alatberat-dibakar/

Batubara, B. (2013, October 4). '65, Konflik Sumber Daya Alam, dan Agenda Gerakan. Harian IndoPROGRESS. https:// indoprogress.com/2013/10/65konflik-sumber-daya-alam-danagenda-gerakan/

Budiarjo, M. (2008). Dasar-Dasar Ilmu Politik. Jakarta: Gramedia Pustaka Utama.

Burhanuddin, B. (2000, July 26). Ulama Sebagai Cultural Broker, Atau Pialang Politik? Media Indonesia.

Creswell, J. W., \& Creswell, J. D. (2018). Qualitative, Quantitative, and Mixed Methods Approaches (fifth). California: SAGE Publications.

Dimyati, M. (2008). Manakib Abuya Cidahu, Dalam Pesona Langkah Di Dua Alam. Pandeglang: NP.

Dinica, V. (2015). Understanding the Role of Behavioural Change Mechanismin Groundwater Use Conflict-Lessons from the Netherland. Journal of Sustainable Society, 7(3).

Doyle, T., \& Dough, M. (2008). Political Theories and Environmental Conflict, in Environment and Politics. London: Routledge.

Forum Anggota Dewan Sumber Daya Air Nasional. (2016). Recommencation for PT. Tirta Freshindo Jaya Project in Pandeglang and Serang.

Hamid, A. (2010). The Kiai in Banten: Shifting Roles in Changing Times in Masaaki (eds) Islam in Contention: Rethinking Islam and State in Indonesia. Wahid Institute. https:// abdulhamid.id/wp-content/ uploads/2012/07/the-kiai-inbanten.pdf

Haynes, J. (1999). Power, politics and environmental movements in the Third World. Environmental Politics, 8(1). https://doi.org/https:// doi.org/10.1080/096440199084144 45

Heijden, H.-A. Van Der. (1999). Environmental Movements, Ecological Modernisation and Political Opportunity Structures. Environmental Politics, 8 (1). $\quad$ https://doi.org/https:// doi.org/10.1080/096440199084144 44

Hikmawan, M. D., \& Hidayat, R. (2016). Depoliticisation of Public Issue : Low Degree of Government ' S Democratic Legitimacy. Journal of Governance, 1 (1), 23-37. https://doi.org/http:// dx.doi.org/10.31506/jog.v1i1.1311

Horikosi, H. (1987). Kiai dan Perubahan Sosial. Jakarta: P3M.

Huma, H. (2019). Meretas Mimpi Hutan Adat (Hacking the Dream of an Indigenous Forest).

Kartodirjo, S. (1984). Pemberontakan Petani Banten 1888. Jakarta: Pustaka Jaya.

Kresna, M. (2017a). Bisnis Mayora Group dari Roma sampai Le Minerale. Tirto.Id. https://tirto.id/bisnis-mayoragroup-dari-roma-sampai-le-minerale -cl4a 
Available Online at https://journal.unismuh.ac.id/index.php/otoritas

Otoritas : Jurnal Ilmu Pemerintahan, 11 (1), April 2021, 32

Kresna, M. (2017b). Tipu-tipu Penutupan Pabrik Mayora Group di Pandeglang. Tirto.Id. https://tirto.id/tipu-tipupenutupan-pabrik-mayora-group-dipandeglang-cl4b

Kuntowijoyo, K. (2001). Muslim tanpa Mesjid. Bandung: Mizan.

Laclau, E., \& Mouffe, C. (2001). Hegemony and Socialist Strategy: Towards a Radical Democratic Politics, Second Edition. London: Verso.

Martono, N. (2011). Sosiologi Perubahan Sosial. Jakarta: Rajawali Press.

Ombudsman Republic of Indonesia. (2016). Letter No. 0120/ KLA/0166.2016/AM-11/TIM.3/ III/2016 about request for clarification regarding follow-up of complaint on behalf of jamiatul muslimin related to alleged environmental crime in establishment of drinking water factory of PT. Tirta Freshindo Jay.

Pandeglang Regency. (2011). Regional Regulation (Peraturan Daerah) No. 3 2011 about Spatial Planning Pandeglang Regency (Rencana Tata Ruang Wilayah Kabupaten Pandeglang 2011-2031).

Porta, D. Della, \& Diani, M. (2006). Social Movements, An Introduction. New Jersey: Blackwell Publishing.
Putra, V. (2017). Pemprov Banten resmi Cabut Izin PT. Mayora. Newsmedia. https://newsmedia.co.id/gubernurbanten-resmi-cabut-ijin-pt-mayora/

Regus, M. (2017). Church-based Resistance to Mining in Manggarai. Inside Indonesia.

https:// www.insideindonesia.org/churchbased-resistance-to-mining-inmanggarai-3

So, A. Y., Lee, L. X. H., \& Yok-Shiu, L. F. (1999). Asia's Environmental Movements Comparative Perspectives. London: Routledge.

Suharko, S. (1998). Model-Model Gerakan NGO Lingkungan, Studi Kasus di Yogyakarta. JSP : Jurnal Ilmu Sosial Dan Ilmu Politik UGM, 2(1), 40-62.

Suharko, S. (2016). Masyarakat Adat versus Korporasi, Konflik Sosial Rencana Pembangunan Pabrik Semen di Kabupaten Pati Jawa tengah Periode 2013-2016. JSP : Jurnal Ilmu Sosial Dan Ilmu Politik UGM, 20(2), 97-116.

Tilly, C., \& Tarrow, S. (2007). Contentious Politics. Colorado: Paradigm Publisher.

Turmudi, E. (2003). Perselingkungan Kiai dan Kekuasaan. Yogyakarta: LKiS., 384-394. 